\title{
Dynamics, Diversity, and Virulence of Aeromonas spp. in Homestead Pond Water in Coastal Bangladesh
}

\begin{abstract}
Abdus Sadique ${ }^{1}$, Sucharit Basu Neogi ${ }^{1}$, Tanvir Bashar ${ }^{1}$, Marzia Sultana ${ }^{1}$, Fatema-Tuz Johura ${ }^{1}$, Saiful Islam ${ }^{1}$, Nur A. Hasan ${ }^{2,3}$, Anwar Huq ${ }^{4}$, Rita R. Colwell ${ }^{2,3,4,5}$ and Munirul Alam ${ }^{1 *}$

${ }^{1}$ icddr, b, Formerly International Centre for Diarrhoeal Disease Research, Bangladesh, Dhaka, Bangladesh, ${ }^{2}$ EzBiome Inc., Gaithersburg, MD, United States, ${ }^{3}$ Center for Bioinformatics and Computational Biology, University of Maryland, College Park, MD, United States, ${ }^{4}$ Maryland Pathogen Research Institute, University of Maryland, College Park, MD, United States, ${ }^{5}$ Johns Hopkins Bloomberg School of Public Health, Baltimore, MD, United States
\end{abstract}

Aeromonads are aquatic bacteria associated with frequent outbreaks of diarrhea in coastal Bangladesh, but their potential risks from environmental sources have remained largely unexplored. This study, over 2 years, examined homestead pond waters in the region for monthly dynamics and diversity of Aeromonas spp. The bacterial counts showed bi-modal annual growth peak, pre- and post-monsoon, strongly correlating $(p<0.0005)$ with temperature. Of 200 isolates characterized, Aeromonas veronii bv. sobria (27\%) was predominant among co-existent Aeromonas schubertii (20\%), Aeromonas hydrophila (17\%), Aeromonas caviae (13\%), and three more. PCR screening of virulence-related genes identified 15 genotypes (I to XV), however, enterotoxigenicity in animal model was observed for five genotypes, ca. 18\% (nine of 50) strains, prevalent in $A$. veronii bv. sobria, $A$. hydrophila, and $A$. caviae. Pathogenic strains were distinguishable by possessing at least three of the major virulence genes: ascV, hlyA, ela, ast, and alt, together with accessory virulence factors. PFGE of Xbal-digested genomic DNA revealed high genetic diversity and distant lineage of potentially toxigenic clones. Therefore, along with increased global warming, Aeromonas spp. having multi-factorial virulence potential in coastal ponds that serve as drinking water sources pose a potential health risk, and underscores the need for routine monitoring.

Keywords: Aeromonas, coastal pond, seasonality, diversity, toxigenic genes, virulence

\section{INTRODUCTION}

The coastal region along the Bay of Bengal, Bangladesh is considered to be one of the most vulnerable areas of the world where climate change mediated impacts are imminent (1). Saline intrusion into the shallow aquifers of this region is a serious problem for millions of rural residents who are vulnerable to waterborne diseases since the ponds serve as their source of water for household purposes, including drinking (2). Recurrent diarrhea and enteric diseases cause serious health problems for the coastal residents, especially children under the age of five. All of the etiologic agents in this disaster-prone region have not been determined. Aeromonads are among the aquatic bacteria associated with water and food-borne diseases in tropical regions (3). These aquatic bacteria are also implicated as causative agents of a variety of disease conditions in aquatic animals, 
including economically important prawns and fishes. In the central inland areas of Bangladesh, Aeromonas spp. have been reported to be associated with gastroenteritis, with a yearly isolation rate between 9 and $16 \%$ of stool samples collected from patients with diarrhea (4). However, there is a lack of information regarding the seasonal abundance, diversity of pathogenic potential, and the molecular traits of Aeromonas spp. in the coastal region of the Bengal delta.

Members of the genus Aeromonas (family Aeromonadaceae) are Gram-negative, rod-shaped bacteria, ubiquitously occurring in various aquatic environments, including freshwater ponds and lakes, sewage waters and brackish waters $(5,6)$. Aeromonas spp. are capable of withstanding a broad range of environmental conditions, e.g., different salinity levels, wide temperature range $\left(4-45^{\circ} \mathrm{C}\right)$ and nutrient-limited conditions $(7,8)$. Changes in the physico-chemical parameters of the coastal waters may modulate abundance of Aeromonas populations and the seasonality of their disease incidence. Gastroenteritis caused by Aeromonas spp. in humans include mild and self-limiting watery diarrhea, chronic diarrhea lasting more than a year and more invasive Shigella-like severe dysentery. Health disasters and life-threatening conditions have been reported, notable in young (under 5 years of age) children and travelers $(9,10)$. Patients infected with aeromonads generally have stools characterized as watery or containing mucus without visible blood and the majority manifest symptoms that include vomiting and abdominal pain, very similar to the classical symptoms of cholera (11). In addition, Aeromonas spp. are associated with extra-intestinal infections in humans, such as lifethreatening septicemia, necrotizing fasciitis, hemolytic-uremic syndrome, meningitis, myonecrosis, and serious lung infections (12). Aeromonas spp. was ranked as the predominant pathogen (20\% the isolates) causing skin or soft tissue infections, among Tsunami survivors (13).

Of the 36 known species of Aeromonas, the most common species isolated from clinical samples include A. hydrophila, A. caviae and $A$. veronii biovar (bv.) sobria (A. sobria), while 15 other species, including A. salmonicida, A. schubertii, A. trota, and $A$. media are also associated with human disease $(10,14)$. A variety of virulence factors of Aeromonas spp. have been characterized, for example, hemolysin $(h l y A)$, cytotonic heatlabile (alt) and heat-stable (ast) enterotoxins, Type II-secreted cytotoxic enterotoxin (act), Type III secretion system (ascV), cytotoxic heat-labile enterotoxin referred to as aerolysin (aerA), flagella ( $f l a)$, lipase (lip), elastase (ela), and protease (pro) (1519). Among the pathogenic factors of Aeromonas spp., secretion of cytotonic and cytotoxic enterotoxins encoded by ast, hlyA, and act genes, and elastase (ela) are considered to be the major virulence determinants linked to diarrhea in experimental animals, e.g., mice and rabbits $(15,20)$. Type III secretion system (TTSS) has been also reported to induce diarrhea (21). Both hlyA and aerA genes encode for hemolysis of red blood cells and damage to tissue culture cell lines $(20,22)$. Accessory pathogenic factors include extracellular secretion of protease and elastase, associated with host tissue damage and facilitating nutrient availability and resistance to host immune response (2325). Some strains of Aeromonas produce lipase during invasion of host organs, facilitating lysis of host erythrocyte plasma membranes (24). Cytotonic enterotoxins ast and alt do not cause degeneration of crypts and villi of the small intestine as observed for the cytotoxic enterotoxins act and aerA (15). Interestingly, the roles of genes encoding for various pathogenic factors in Aeromonas have not been determined in detail and pathogenesis, with respect to Aeromonas, is considered to be complex and multi-factorial (10). In this context, aquatic Aeromonas populations in the coastal environment of Bangladesh merits investigation. The objective of this study was to determine the spatio-temporal dynamics and diversity of potentially virulent Aeromonas spp. in homestead pond waters commonly used by resident people for household purposes in the coastal region of Bangladesh.

\section{METHODS}

\section{Study Area and Field Sampling}

Water samples were collected each month during June, 2005 to September, 2007 from two homestead ponds $(\sim 0.2$ ha each and $2-3 \mathrm{~m}$ depth), one in coastal Mathbaria and the other in Bakerganj districts of Bangladesh (Figure 1). Both ponds are located near a tidally influenced tributary of the GangesBrahmaputra river system. Located along the western boundary of Mathbaria is the "Sundarban," the largest tropical mangrove forest in the world. The Bakergonj study site is located $\sim 50 \mathrm{~km}$ upstream of Mathbaria. During each sampling five sub-samples of sub-surface water (ca. $0.5 \mathrm{~m}$ depth) were collected in a sterilized bucket from each of the four corners and at the middle point of the ponds and pooled. The samples, transported in $1.0 \mathrm{~L}$ sterile plastic bottles in an insulated plastic box, were collected between noon to 2.0 p.m. and processed within $18 \mathrm{~h}$ of collection. Temperature, $\mathrm{pH}$, salinity, conductivity and dissolved oxygen (DO) of sub-surface water were measured at each sampling, employing a Sens-Ion III multi parameter device (HACH Co. Loveland, Cleveland, USA), according to manufacturer's instruction.

\section{Isolation and Identification of Aeromonas spp.}

A $100 \mathrm{ml}$ portion of each of the water samples were filtered through a $0.22 \mu \mathrm{m}$ polycarbonate membrane filter (Millipore Corp., Bedford, MA, USA), and the concentrated particulates, including bacteria on filter was re-suspended in $2.5 \mathrm{~mL}$ phosphate-buffered saline ( $\mathrm{pH} 7.5)$ for microbiological analysis. The concentrated bacteria in water samples (100 $\mu \mathrm{L}$ fractions) were cultured on Ryan's Aeromonas medium and TCBS agar medium (Difco Laboratories, Detroit, MI, USA) and incubated at $37^{\circ} \mathrm{C}$ for $24-48 \mathrm{~h}$. In addition, a $1 \mathrm{~mL}$ portion of the concentrated water sample was enriched in $9 \mathrm{~mL}$ alkaline peptone water (Difco) at $37^{\circ} \mathrm{C}$ for 6 to $8 \mathrm{~h}$ before plating on selective media, as described elsewhere (5).

For each sample, 10 colonies typical of Aeromonas spp. were selected and screened for cytochrome oxidase and gelatinase production, susceptibility to O/129 (2,4-diamino6,7-diisopropylpteridine, $150 \mu \mathrm{g}$ ), and growth at various salt concentrations $(0,6.5$, and $8 \% \mathrm{NaCl})$. The phenotypically confirmed Aeromonas colonies in $100 \mu \mathrm{L}$ of concentrated water 


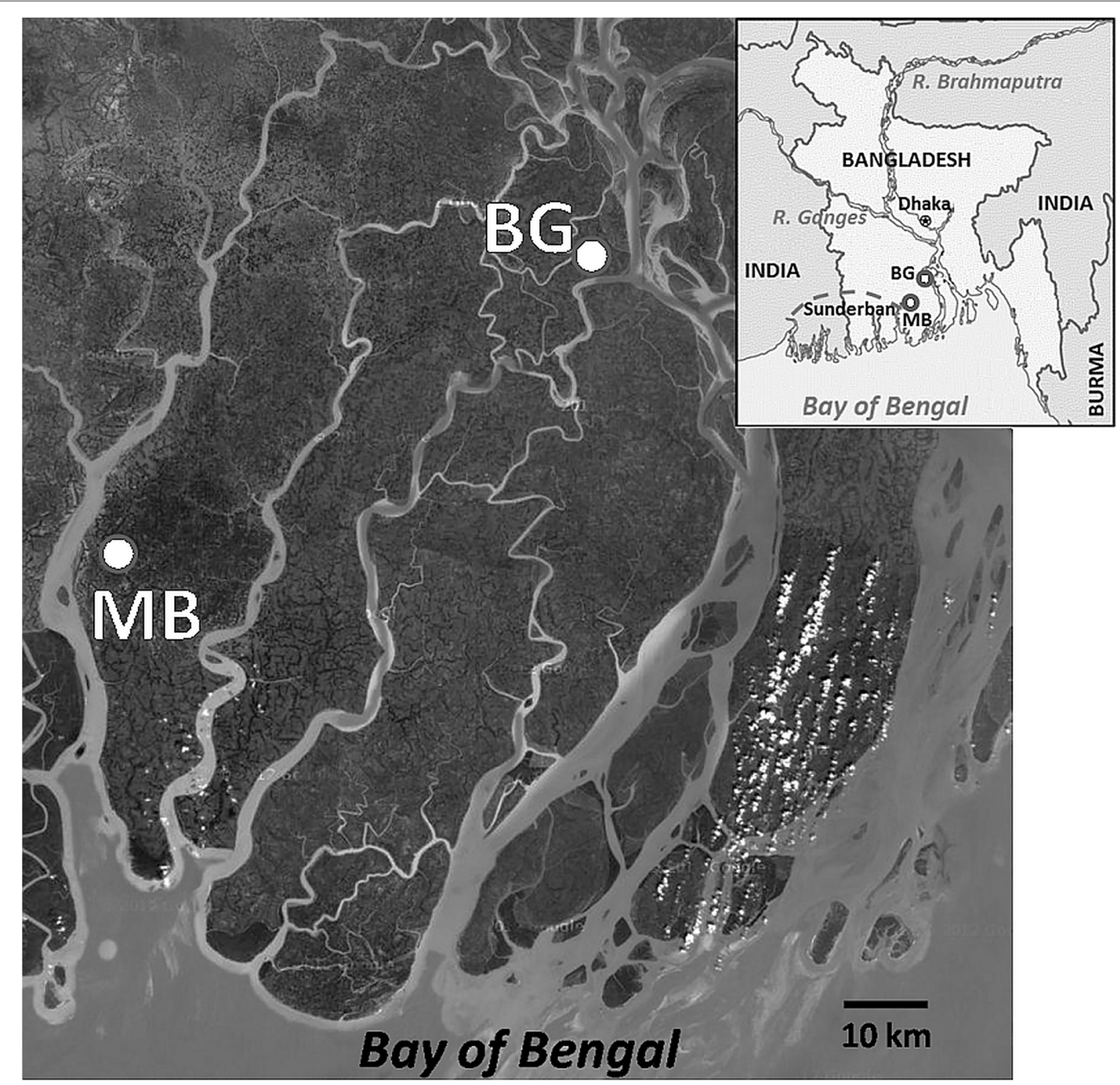

FIGURE 1 | A geographical view of the study areas in the coastal villages of the Bengal delta, Bangladesh. Location of study sites, Mathbaria (MB) and Bakergonj (BG), are shown by closed circles. Inset showing a map of Bangladesh, including areas where water samples were collected from the coastal zones of the Ganges-Brahmaputra river basin. Locations of Dhaka, the capital of Bangladesh, and Sundarban, the largest mangrove wetland in the world, are also shown. This has been taken from Google Map.

samples was determined by counting colony forming unit (CFU) on selective media. The total count in the original sample were estimated by back calculation with the concentration factor (40X). A total of 200 isolates, including 1-4 representative(s) from each of the Aeromonas-positive samples, were identified to species level, employing the Aero key II scheme and other biochemical tests, as described elsewhere (26). All isolates were preserved as glycerol stock, according to standard methods, and stored at $-80^{\circ} \mathrm{C}$.

\section{Hemolytic Activity}

Representative Aeromonas strains were examined for alpha $(\alpha)$ and beta $(\beta)$ hemolytic activity on blood agar plates, supplemented with $5 \%$ de-fibrinated sheep blood, following a previously established method (27).

\section{Antimicrobial Susceptibility}

Antimicrobial susceptibility testing for the isolated strains of Aeromonas spp. was performed by disc diffusion method 
using Muller Hinton agar (Difco) following WHO guidelines (www.who.int/csr/resources/publications/drugresist/en/IIIAMR Manual.pdf). Seven different antimicrobial agents (Oxoid, Hampshire, UK) commonly used to treat diarrhea, e.g., tetracycline $(30 \mu \mathrm{g})$, furazolidone $(100 \mu \mathrm{g})$, cephalothin $(30 \mu \mathrm{g})$, erythromycin $(15 \mu \mathrm{g})$, gentamicin $(10 \mu \mathrm{g})$, ciprofloxacin $(5 \mu \mathrm{g})$, and trimethoprim/sulfamethoxozole $(1.25 / 23.75 \mu \mathrm{g})$, were used. The diameters of the inhibition zones were interpreted according to the standards for antimicrobial susceptibility testing (28). E. coli ATCC 25922 was included for quality control.

\section{Detection of Virulence Genes}

Cells were harvested from overnight cultures of Aeromonas strains in Luria-Bertani broth (Difco) and genomic DNA was extracted following standard method as described elsewhere (29). PCR assays were performed using genomic DNA of each strain as template to detect the presence of enterotoxins and virulencerelated genes of Aeromonas spp., including aerolysin (aerA), heat labile and stable enterotoxin (alt and ast), haemolysin ( $h l y A$ ), Type II-secreted cytotoxic enterotoxin (act), TTSS (ascV), flagella subunit protein $(f l a)$, regulatory elastase $(\mathrm{ela})$, protease (pro) and lipase (lip), employing previously described primers and PCR conditions (Table 1). Samples $(3 \mu \mathrm{l})$ were added to the PCR mixture to achieve a $30-\mu$ l final volume containing a $0.21 \mathrm{mM}$ concentration of each deoxynucleoside triphosphate mixture, $50 \mathrm{mM} \mathrm{KCl}, 1.5 \mathrm{mM} \mathrm{MgCl} 2,10 \mathrm{mM}$ Tris- $\mathrm{HCl}$ ( $\mathrm{pH} 8.3$ ), $0.17 \mu \mathrm{M}$ primer pair and $0.75 \mathrm{U}$ of Taq polymerase (Takara, Kyoto, Japan). Amplification conditions used were $5 \mathrm{~min}$ at $94^{\circ} \mathrm{C}$ for initial denaturation of DNA and 30 cycles, each consisting of $1 \mathrm{~min}$ at $94^{\circ} \mathrm{C}, 1 \mathrm{~min}$ at $55^{\circ} \mathrm{C}$, and $1 \mathrm{~min}$ at $72^{\circ} \mathrm{C}$, with a final round of extension for $7 \mathrm{~min}$ at $72^{\circ} \mathrm{C}$ in a DNA RoboCycler gradient temperature cycler (Stratagene, La Jolla, Calif.). The PCR products were subjected to $1.5 \%$ agarose gel electrophoresis in TAE buffer ( $40 \mathrm{mM}$ Tris-acetate, $1 \mathrm{mM}$ EDTA), followed by staining in ethidium bromide solution $\left(2 \mu \mathrm{g} \mathrm{ml}^{-1}\right)$ and destaining in distilled water for 5-10 min each. Images were captured by Gel-Doc 2000 (Bio-Rad, Hercules, CA, USA).

The presence of putative virulence genes among various Aeromonas strains were also confirmed by colony hybridization. A positively amplified PCR product of each gene was purified after agarose gel electrophoresis using the gel extraction kit (QIAGEN, Hilden, Germany) and labeled with digoxigenin (DIG) using a commercial kit according to manufacturer's instructions (Roche Diagnostics GmbH, Mennheim, Germany). Freshly cultured Aeromonas colonies were grown on nitrocellulose membranes $(0.22 \mu \mathrm{m}$, Millipore Corp.) overlaid on LB Agar (Difco) at $37^{\circ} \mathrm{C}$ for $4-6 \mathrm{~h}$. The colonies were lysed, using denaturation solution $(0.5 \mathrm{M} \mathrm{NaOH})$ for $10 \mathrm{~min}$, followed by exposure three times in neutralization solution $(1 \mathrm{M}$ Tris- $\mathrm{HCl}, \mathrm{pH}$ 7.0) for $1 \mathrm{~min}$ each and finally treated with $1 \mathrm{M}$ Tris- $\mathrm{HCl}$ ( $\mathrm{pH} 7.0$ ), $1.5 \mathrm{M} \mathrm{NaCl}$ for $10 \mathrm{~min}$. The membranes were air-dried and DNA was cross-linked to the membrane by UV irradiation for $5 \mathrm{~min}$. The blots, thus prepared, were subjected to a hybridization with the DIG-labeled PCR products of target genes as probes using the DIG detection kit (Roche Diagnostics $\mathrm{GmbH}$ ) according to manufacturer's instruction.

\section{Virulence Potential}

The enterotoxigenic potential of selected environmental strains of Aeromonas spp. was examined in both the rabbit ileal loop (RIL) and suckling mice assay (SMA). Culture filtrates (CF) of representative Aeromonas strains belonging to different species and having different virulence gene profiles were prepared as described previously (27). Culture filtrates of cholera toxin (CT) positive Vibrio cholerae 569B and sterile media (Luria Bertani Broth) were used as positive and negative controls, respectively.

The RIL assay was performed using adult New Zealand white rabbits ( $\sim 2.0 \mathrm{~kg})$ following a previously established method (33). Briefly, $1 \mathrm{ml}$ of CF was injected into each loop of a rabbit ileum, following laparotomy, and the inoculated rabbits were sacrificed after $16-18 \mathrm{~h}$ to measure the volume of fluid accumulation per $\mathrm{cm}$ of gut in each rabbit. Fluid accumulation of $\geq 0.5 \mathrm{ml} \mathrm{cm}^{-1}$ of gut was considered as a positive response in the RIL.

The SMA was performed using 3 days old Swiss albino suckling mice, according to standard procedures as described previously (34). Briefly, an aliquot $(0.1 \mathrm{ml})$ of the CF containing $0.01 \%(w / v)$ Evans Blue was injected directly into the stomach of each suckling mouse and after $4-5 \mathrm{~h}$ of incubation the mouse was sacrificed, and its intestine was removed and weighed. A fluid accumulation score, in SMA, was expressed as the ratio of weight of the intestine to the remaining body weight and a ratio of $\geq 0.08$ was considered as positive. Enterotoxigenic potential of each strain was verified in triplicate.

The experimental animals were reared at the animal resources facility of icddr,b in accordance with the Guide for the Care and Use of Laboratory Animals (1996, published by National Academy Press, 2101 Constitution Ave. NW, Washington, DC 20055, USA). The Animal Experimentation Ethics Committee (AEEC) of icddr,b approved the study protocol.

\section{Genomic Diversity and Clonal Relationship}

To determine genomic diversity of the coastal Aeromonas populations, representative strains were subjected to pulsed field gel electrophoresis (PFGE). Bacterial cells were harvested from colonies grown overnight at $37^{\circ} \mathrm{C}$ on Trypticase Soy Agar (Difco), supplemented with 5\% defibrinated sheep blood, and suspended in cell suspension buffer $(100 \mathrm{mM}$ Tris- $\mathrm{HCl}, 100 \mathrm{mM}$ EDTA, pH 8.0). The cell suspensions, after adjusting absorbance to ca. $0.64-0.66$ at $560 \mathrm{~nm}$, were mixed at $56^{\circ} \mathrm{C}$ with an equal volume of $1 \%$ SeaKem ${ }^{\circledR}$ Gold Agarose (Cambrex Bioscience Rockland, Inc., Rockland, ME, USA) in TE buffer (10 mM Tris and $1 \mathrm{mM}$ EDTA, $\mathrm{pH}$ 8.0) and solidified in plug molds (Bio-Rad Laboratories, Richmond, CA, USA). Gel plugs were incubated with cell lysis buffer (50 mM Tris, $50 \mathrm{mM}$ EDTA, and $1 \% \mathrm{~N}$ lauroyl sarcosine) for $2 \mathrm{~h}$ at $55^{\circ} \mathrm{C}$ with vigorous shaking followed by twice washing in autoclaved distilled water at $50^{\circ} \mathrm{C}$ for $15 \mathrm{~min}$ each and four times washing in TE buffer at $50^{\circ} \mathrm{C}$ for $1 \mathrm{~h}$ each. The gel plug was digested with $20 \mathrm{U}$ of $\mathrm{XbaI}$ (Invitrogen, Life Technologies, NY, USA) in 200- $\mu \mathrm{l}$ reaction volumes for at least $4 \mathrm{~h}$ at $37^{\circ} \mathrm{C}$. PFGE was performed using $1 \%$ PFGE certified agarose (Bio-Rad) and 0.5X TBE (0.089 M Tris, 0.089 M boric acid, 0.002 M EDTA) running buffer in a CHEF MAPPER (Bio$\mathrm{Rad}$ ). Electrophoresis was done at six volts for $18 \mathrm{~h}$ (initial switch time $2.2 \mathrm{~s}$; final switch time $63.8 \mathrm{~s}$ ). Salmonella braenderup, a 
TABLE 1 | Details of PCR assays targeting virulence genes of Aeromonas spp.

\begin{tabular}{|c|c|c|c|c|}
\hline $\begin{array}{l}\text { Sl. } \\
\text { No. }\end{array}$ & $\begin{array}{l}\text { Target } \\
\text { gene }\end{array}$ & Primer sequence $\left(5^{\prime}\right.$ to $\left.3^{\prime}\right)$ & $\begin{array}{l}\text { Amplicon } \\
\text { size (bp) }\end{array}$ & References \\
\hline \multirow[t]{2}{*}{1} & ascl & ATGGACGGCGCCATGAAGTT & 710 & (21) \\
\hline & & ТАTTCGCCTTCACCCATCCC & & \\
\hline \multirow[t]{2}{*}{2} & hlyA & CCACGCAAATTCATCACG & 1,079 & (30) \\
\hline & & АTCCTTGTTCACCTCGAC & & \\
\hline \multirow[t]{2}{*}{3} & ela & ACACGGTCAAGGAGATCAAC & 513 & (18) \\
\hline & & CGCTGGTGTTGGCCAGCAGG & & \\
\hline \multirow[t]{2}{*}{4} & ast & ТСTССАТGСТTСССТTССАСТ & 331 & (18) \\
\hline & & GTGTAGGGATTGAAGAAGCCG & & \\
\hline \multirow[t]{2}{*}{5} & alt & TGACCCAGTCCTGGCACGGC & 442 & (18) \\
\hline & & GGTGATCGATCACCACCAGC & & \\
\hline \multirow[t]{2}{*}{6} & act & AGAAGGTGACCACCAAGAACA & 232 & (31) \\
\hline & & AACTGACATCGGCCTTGAACTC & & \\
\hline \multirow[t]{2}{*}{7} & aerA & CTGGTCTGGATAGACGGGCTCTGCC & 416 & (32) \\
\hline & & GCCTGAGCGAGAAGGT & & \\
\hline \multirow[t]{2}{*}{8} & pro & ATGACTAACCCTITGCTG & 1,038 & (30) \\
\hline & & GAACTTGTGCTGCTTGAG & & \\
\hline \multirow[t]{2}{*}{9} & lip & АTCTTCTCCGACTGGTTCGG & 382 & (18) \\
\hline & & CCGTGCCAGGACTGGGTCTT & & \\
\hline \multirow[t]{2}{*}{10} & fla & TCCAACCGTYTGACCTC & 608 & (18) \\
\hline & & GMYTGGTTGCGRATGGT & & \\
\hline
\end{tabular}

control strain for DNA size markers, was also subjected to PFGE at each step. Following electrophoresis, the gels were stained for $30 \mathrm{~min}$, de-stained twice for $15 \mathrm{~min}$ each, and pictures captured using a Gel-Doc 2000 (Bio-Rad).

To determine clonal relationships among the Aeromonas strains, PFGE patterns in gel images were subjected to cluster analysis by the unweighted-pair group method using average (UPGMA) and the band-based (Dice coefficient) option was applied during dendogram similarity calculation using BioNumerics (Applied Maths BVBA, Sint-Martens-Latem, Belgium). Pulsotypes were determined considering a $90 \%$ cut-off of the similarity index, while estimating their clonal lineage.

\section{Statistical Analysis}

Statistical analyses were carried out using "Xact" (version 7.21d, SciLab, Saint Yrieix, France) and Statistical (ver. 10.0, StatSoft, Oklahoma, USA). Non-parametric Spearman rank correlations were used for the data analysis. Regression fits were applied to explore correlations between variables, including environmental factors and bacterial abundance. A $p<0.05$ was considered as significant.

\section{RESULTS}

\section{Physicochemical Parameters}

In both study areas, the water temperature during sample collection ranged from 18 to $25^{\circ} \mathrm{C}$ during the winter season (December to February) and $25-36^{\circ} \mathrm{C}$ during the warmer months (March-November). The monsoon season, characterized by frequent precipitation, extended from June to October.
The Mathbaria site had comparatively higher salinity (0.22.4 practical salinity unit [PSU]) than Bakergonj (0.0-0.3 PSU). Similarly, TDS values were also higher at Mathbaria (190-2,200 $\mathrm{mg} \mathrm{L}^{-1}$ ) than Bakergonj (67-195 $\mathrm{mg} \mathrm{L}^{-1}$ ), and their seasonal peaks also showed distinct spatial variation (Figure 2). Water $\mathrm{pH}$ was relatively higher at Mathbaria (7.39.8) than Bakergonj (6.7-8.5). Variation in DO (4.2-9.6 mg $\mathrm{L}^{-1}$ ) was independent of season or site. A clear influence of monsoon rainfall, leading to reduced salinity and TDS was observed at Bakergonj during May-September. However, further downstream from the Mathbaria site, the impact of rainfall was not discernible, probably, because of a significant impact of tidal flushing.

\section{Seasonal Dynamics of Aeromonas spp.}

Aeromonas spp. were isolated from $82 \%$ (46 out of 56) samples, with higher abundance during the summer months $\left(>25^{\circ} \mathrm{C}\right.$ of water temperature) and low or no culturable counts during winter months (Figure 2). The yearly isolation rate of Aeromonas spp. was higher in pond water at Mathbaria, which is located closer to the Bay of Bengal shoreline than Bakergonj pond water (Supplementary Table 1). However, Aeromonas counts exhibited a bi-modal pattern annually, reaching $>10^{4} \mathrm{CFU}$ $100 \mathrm{ml}^{-1}$, during pre-monsoon spring (April-May) and at the autumn (September-October), at both study sites (Figure 2).

No difference in the Aeromonas species diversity was observed between the two study sites. Overall, seven species of Aeromonas were identified after screening 200 isolates. Among them, A. veronii bv. sobria (27.0\%) dominated, followed by $A$. schubertii (19.5\%) and A. hydrophila (17\%), whilst A. caviae (13\%), A. trota (12.0\%), and A. eucrenophila (7.0\%) were isolated intermittently. $A$. veronii bv. sobria and $A$. schubertii were frequently isolated throughout the year, while A. allosaccharophila was rarely (4.5\%) isolated (Figure 2). Notably, along with the increased occurrence of culturable population, the diversity of Aeromonas spp. was significantly higher during pre-monsoon (April-May, late spring/early summer) and post-monsoon (September-October, autumn) time of the year. Seasonal variations in Aeromonas species diversity were similar for both of the study sites (Supplementary Table 1).

\section{Influence of Physico-Chemical Parameters on Aeromonas Dynamics}

Highly significant $(p<0.0005)$ correlation was observed between water temperature and total culturable Aeromonas spp., notably during the dry period (December to May), and at temperatures $>25^{\circ} \mathrm{C}$, explaining $\sim 70 \%$ of variations in bacterial abundance (Figure 3). During the wet monsoon, despite warmer climate, the temperature influence on Aeromonas populations was minimized, yet significantly $(p<0.05)$ explaining $44 \%$ of the variations in the bacterial culturable populations. Except for water temperature, no other physico-chemical parameters, including $\mathrm{pH}$, temperature, $\mathrm{DO}$, salinity, and TDS, was found to have any significant influence on Aeromonas abundance in water bodies. 


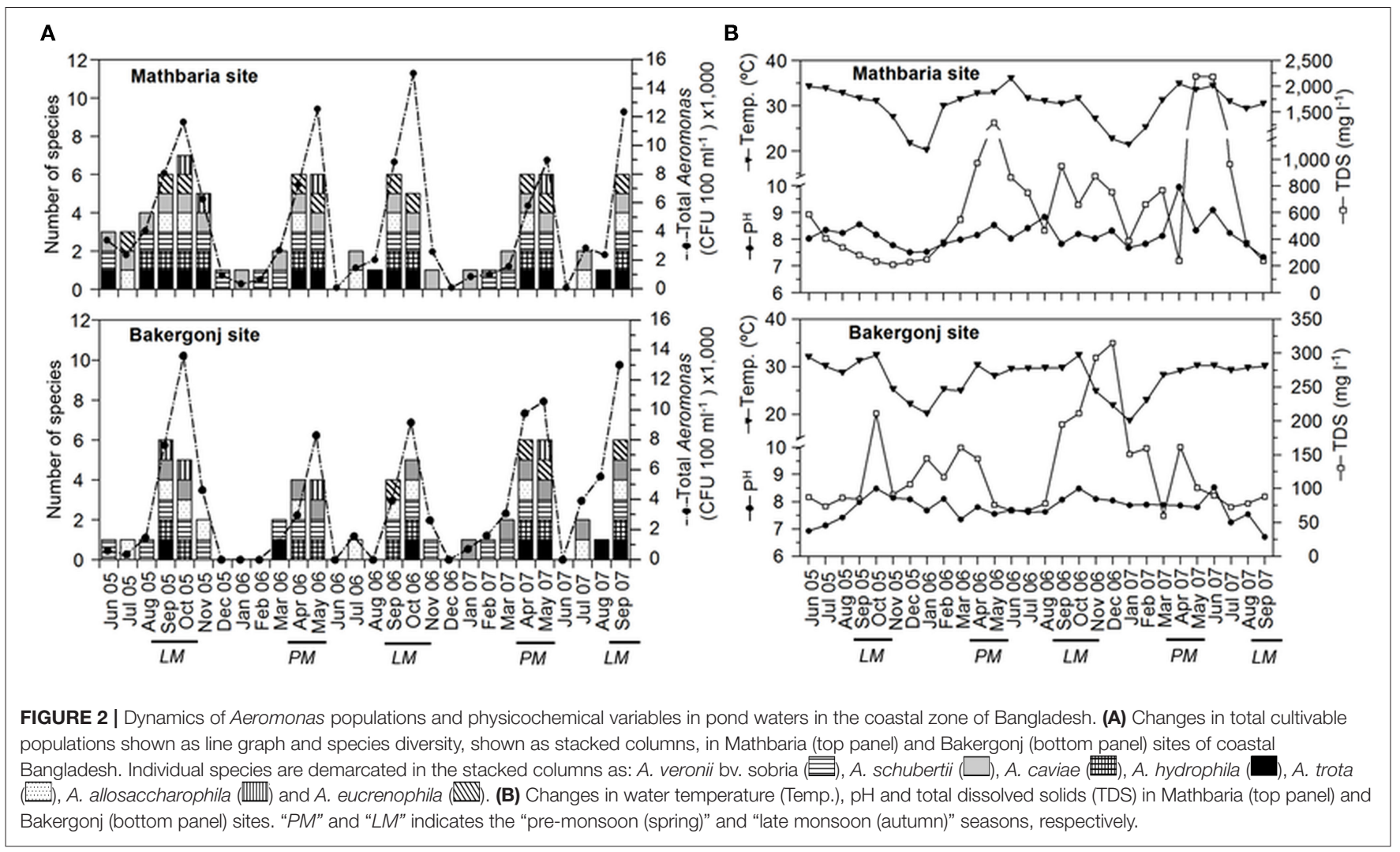

A

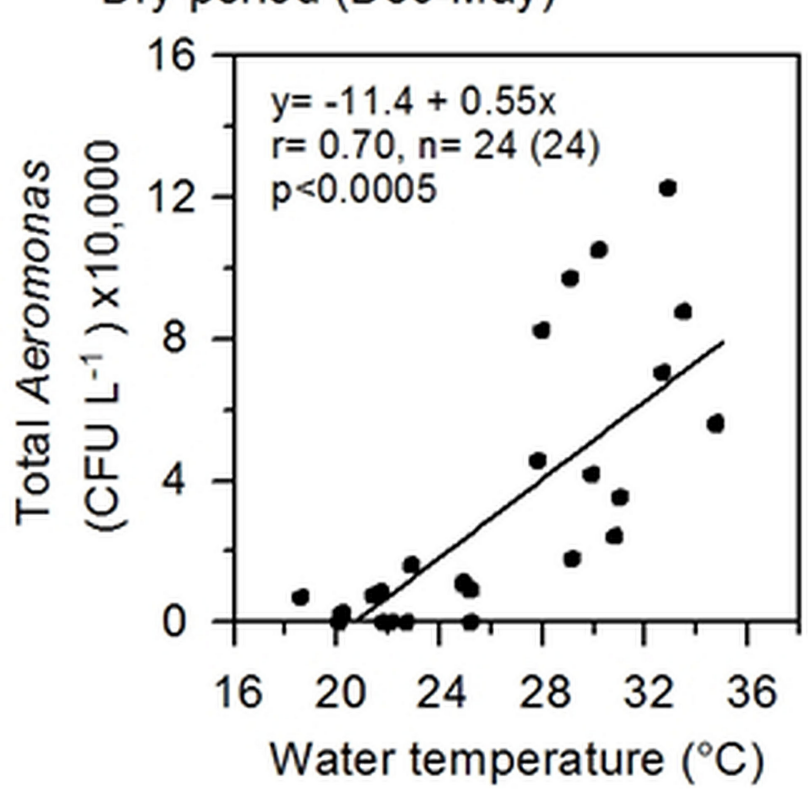

B

Wet (monsoon) period (Jun-Nov)

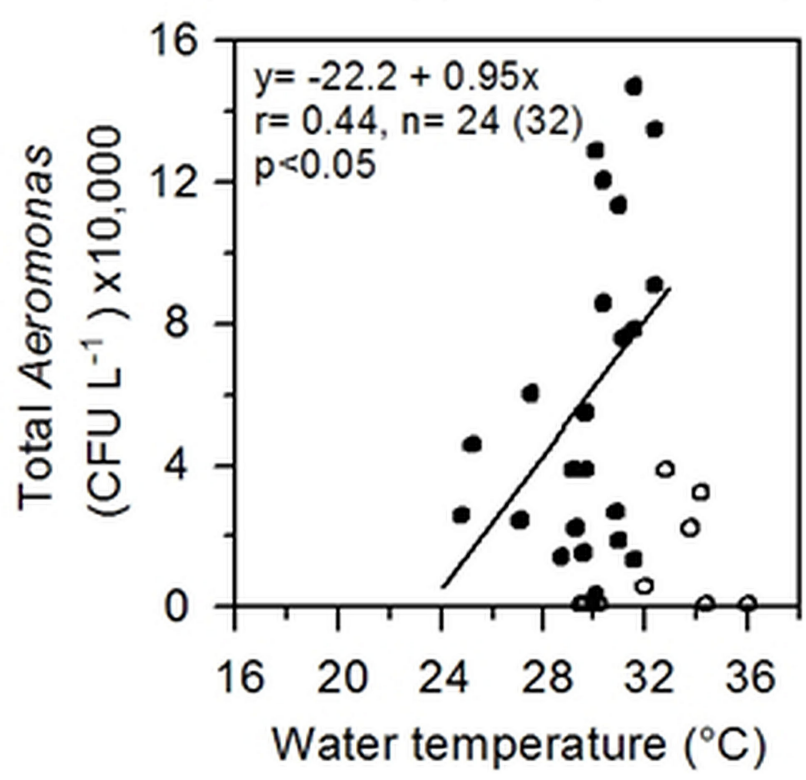

FIGURE 3 | Correlation between Aeromonas abundance and water temperature. (A) Correlation during the dry period (December to May); (B) Correlation during the wet period (June to November), excluding eight outliers. Lines represent linear regressions; relevant information including regression equation, "r" and "p" values are shown inside each box. Correlating data are shown as filled circles (dots) and the outliers as empty circles. 


\section{Hemolytic Activity}

On blood agar, 35 of 50 (74\%) Aeromonas strains had shown hemolytic activity. The majority (74\%) of the strains were $\beta$ hemolytic and only seven (14\%) were $\alpha$-hemolytic (Table 2). The $\alpha$-hemolytic strains included $A$. veronii $(n=4), A$. caviae $(n$ $=2$ ), and $A$. hydrophila $(n=1)$. Six strains, including all $A$. eucrenophila $(n=3)$, and one each of $A$. schubertii, $A$. trota, and A. allosaccharophila showed no hemolytic activity.

\section{Antimicrobial Resistance Patterns}

A total of 50 representative Aeromonas strains were screened for their response to seven commonly used antimicrobial agents. Except for A. veronii $(n=14)$, all strains of different Aeromonas species $(n=36)$ were resistant to Cephalothin. However, all Aeromonas strains were found to be susceptible to the remaining six antimicrobial agents tested.

\section{Occurrence of Toxin Genes}

The major virulence determinants, i.e., genes associated with enterotoxigenicity, namely, asc $V$, ast, hly $A$, and ela, encoding TTSS, cytotonic heat-stable enterotoxin, elastase, and hemolysin, were detected in 18,28, 14, and 22\%, respectively (Table 2). The gene ast was infrequently detected in A. veronii bv. sobria, A. hydrophila, A. caviae, and A. schubertii. Gene hlyA was detected only in a few of $A$. veronii $(n=4)$, A. caviae ( $n$ $=2)$, and $A$. hydrophila $(n=1)$ strains, which correlated with the $\alpha$-hemolytic activity of these strains on Blood Agar. Similarly, the asc and ela genes were found in a few strains of these three species of Aeromonas. The accessory virulencerelated genes encoding flagella $(f l a)$, lipase (lip), protease (pro), aerolysin (aerA), cytotoxic enterotoxin ( $a c t$ ), and cytotonic heatlabile enterotoxin (alt) were detected in $86,80,78,70,56$, and $48 \%$, respectively, of Aeromonas strains. However, occurrence of these genes showed variations (between 40 and 100\%) in different species (Table 2). Aeromonas strains $(n=15)$, which did not show any hemolytic activity, lacked aer $A$, act, and $h l y A$, whereas all strains carrying aer $A$ were found to be $\beta$-hemolytic on Blood Agar. Overall, occurrence of toxin encoding genes was higher among the strains belonging to $A$. veronii bv. sobria, $A$. hydrophila, and A. caviae.

\section{Distribution and Prevalence of Virulence Genotypes}

Approximately 15 "virulence genotypes," designated as "genotype I" to "genotype XV," could be differentiated among 50 representative Aeromonas strains (Table 3). The first five genotypes (I-V) harbored all or most of the major virulence determinants, i.e., ascV, ast, hlyA, ela, act, aerA, and alt, in addition to accessory virulence-related genes. Genotype I harbored all virulence-associated genes tested, except alt. Genotypes II-V harbored eight virulence genes, whereas genotypes VI- X, XI-XII, XIII-XIV, and XV harbored 5, 4, 3, and 1 of 10 virulence-associated genes, respectively (Table 3). Genotype VII (act-aerA-pro-lip-fla), distributed among four species ( $A$. schubertii, A. veronii bv. sobria, A. hydrophila, and A. trota), had the highest prevalence (16\%). A. veronii revealed greater diversity, in terms of distribution of representative strains into multiple virulence genotypes than other species.

\section{Enterotoxigenic Potential in Animal Model Experiments}

Three Aeromonas species (18\% of the total) belonging to genotypes I to V, i.e., A. veronii bv. sobria, A. hydrophila, and $A$. caviae accumulated fluid in the experimental rabbit and mouse intestine, and hence concluded to be enterotoxigenic (Table 3). Both SMA and RIL in vivo assays yielded similar results (Supplementary Table 2). In RIL experiments, fluid accumulation (FA) ratio ranged between 0.9 and $1.4 \mathrm{ml}$ $\mathrm{cm}^{-1}$, while the SMA score ranged between 0.09 and 0.13 for enterotoxigenic strains. However, none of A. schubertii, A. trota, A. eucrenophila, or A. allosaccharophila induced significant fluid accumulation in both assays. The majority of Aeromonas classified as genotypes VI-XV were not enterotoxigenic in mice intestine and rabbit ileal loop assays. Interestingly, Aeromonas strains enterotoxigenic in experimental animals were observed to possess multiple virulence genes, including ascV, ast, hly $A$, alt, act, and aerA (Table 3). Among putative accessory virulence factors, selective presence of the ela gene was observed among the enterotoxigenic strains, along with co-occurrence of the lip, fla, and pro genes. Overall, the animal experiments suggest that, without the combined presence of the five major virulence determinants, ascV-ast-hlyA-ela-alt, or at least three of them, namely ascV-hlyA-alt, ascV-ast-ela, or hlyAela-alt, Aeromonas strains did not cause fluid accumulation (Supplementary Table 2).

\section{Genomic Diversity and Clonal Relationship}

PFGE analysis of XbaI digested chromosomal DNA of representative Aeromonas strains yielded 19-28 reproducible DNA fragments, ranging in approximate sizes from $<20$ to $500 \mathrm{kbp}$ (Figure 4). DNA fingerprints showed high genetic diversity, reflected by the identification of 22 pulsotypes (P1 to P22) of 26 selected strains. Seven distinct pulsotypes were obtained for nine strains of $A$. veronii bv. sobria, and similarly, high genetic divergence was also observed among the other Aeromonas species.

All five genotypes were enterotoxic by RIL and SMA. The strains were genetically heteroenous as they clustered into five pulsotypes (P3, P6, P12, P14, and P22). Conversely, identical pulsotype was observed for a few strains belonging to different genotypes (Figure 4).

Overall cluster analysis by dendrogram of the deduced pulsotypes revealed heterogeneity and distant clonal relationship among these coastal Aeromonas strains, which included those that were enterotoxigenic (Figure 4). Clonally identical Aeromonas strains of pulsotype P3 (enterotoxigenic, genotype V) were detected in both of the years 2005 and 2007, whereas, a dissemination of $A$. caviae strains of pulsotype P14 (enterotoxigenic, genotype I) in both Bakergonj and Mathbaria was remarkable. 
TABLE 2 | Occurrence of virulence related genes and hemolytic activity among the strains of different Aeromonas species.

\begin{tabular}{|c|c|c|c|c|c|c|c|c|c|c|c|}
\hline \multirow[t]{2}{*}{ Species ( $n$ ) } & \multicolumn{10}{|c|}{ Genes related to pathogenicity $[n(\%)]$} & \multirow[t]{2}{*}{ Hemolytic activity* $[n(\%)]$} \\
\hline & $\operatorname{ascV}$ & hlyA & ela & ast & act & aerA & alt & pro & lip & fla & \\
\hline A. veronii bv. sobria (14) & $3(21)$ & $4(29)$ & $5(21)$ & $5(36)$ & $7(50)$ & $8(57)$ & $11(79)$ & $10(71)$ & $12(86)$ & $13(93)$ & $4 \alpha(29), 9 \beta(64)$ \\
\hline A. schubertii (10) & $0(0)$ & $0(0)$ & $0(0)$ & $3(30)$ & $4(40)$ & $8(80)$ & $7(70)$ & $7(70)$ & $8(80)$ & $8(80)$ & $9 \beta(90)$ \\
\hline A. hydrophila (9) & $3(33)$ & $1(11)$ & $3(33)$ & $3(33)$ & $6(67)$ & $4(44)$ & $8(89)$ & $8(89)$ & $8(89)$ & $9(100)$ & $1 \alpha$ (33), $8 \beta$ (89) \\
\hline A. caviae (7) & $3(43)$ & $2(29)$ & $3(43)$ & $3(43)$ & $3(43)$ & $4(57)$ & $5(71)$ & $5(71)$ & $7(100)$ & 7 (100) & $2 \alpha(29), 4 \beta(57)$ \\
\hline A. trota (5) & $0(0)$ & $0(0)$ & $0(0)$ & $0(0)$ & $4(80)$ & $3(60)$ & $4(80)$ & $4(80)$ & $4(80)$ & $4(80)$ & $5 \beta(100)$ \\
\hline A. eucrenophila (3) & $0(0)$ & $0(0)$ & $0(0)$ & $0(0)$ & $0(0)$ & $0(0)$ & $0(0)$ & $3(100)$ & $0(0)$ & $0(0)$ & $3 \beta(100)$ \\
\hline A. allosaccharophila (2) & $0(0)$ & $0(0)$ & $0(0)$ & $0(0)$ & $1(50)$ & $1(50)$ & $1(50)$ & $2(100)$ & $1(50)$ & $2(100)$ & $1 \beta(50)$ \\
\hline Overall (50) & $9(18)$ & $7(14)$ & $11(22)$ & $14(28)$ & $25(50)$ & $28(56)$ & $34(68)$ & $39(78)$ & $40(80)$ & $43(86)$ & \\
\hline
\end{tabular}

$n=50$; ${ }^{*} \alpha$ and $\beta$ designates the alpha and beta hemolytic activities on blood agar medium, respectively.

TABLE 3 | Distribution, prevalence, and virulence potential of the genotypes detected in Aeromonas strains isolated from coastal ponds in Bangladesh.

\begin{tabular}{|c|c|c|c|c|c|c|c|c|c|c|c|c|c|}
\hline \multirow[t]{2}{*}{ Genotype } & \multicolumn{10}{|c|}{ Virulence related genes } & \multirow{2}{*}{$\begin{array}{l}\text { Distribution \& occurrence* } \\
\text { Species }(n)\end{array}$} & \multirow{2}{*}{$\begin{array}{l}\text { Prevalence }^{\dagger} \\
(\%)\end{array}$} & \multirow[t]{2}{*}{ Virulence potential $^{\S}$} \\
\hline & ascV & hlyA & ela & ast & alt & act & aerA & pro & lip & fla & & & \\
\hline I & + & + & + & + & - & + & + & + & + & + & Ac (2) & 4 & ET \\
\hline$\|$ & + & - & + & + & + & - & + & + & + & + & Ah (2) & 4 & ET \\
\hline III & + & + & + & + & - & - & + & + & + & + & Av (2) & 4 & ET \\
\hline IV & + & + & - & - & + & + & + & + & + & + & Ah (1) & 2 & ET \\
\hline V & - & + & + & - & + & + & + & + & + & + & Av (2) & 4 & ET \\
\hline $\mathrm{VI}$ & - & - & - & + & + & - & + & - & + & + & $A v(2), A h(1), A c(1), A s(1)$ & 10 & NT \\
\hline VII & - & - & - & - & - & + & + & + & + & + & As (3), Av (2), Ah (2), At (1) & 16 & NT \\
\hline VIII & - & - & - & - & + & - & + & + & + & + & At (2), Ac (2), Av (1), Ah (1) & 12 & NT \\
\hline IX & - & - & + & - & - & + & - & + & + & + & $\operatorname{Ac}(1), \operatorname{Ah}(1), \operatorname{Av}(1)$ & 6 & NT \\
\hline$x$ & - & - & - & + & - & + & + & + & - & + & As (2), Av (1) & 6 & NT \\
\hline XI & + & - & - & - & - & + & - & - & + & + & $A c(1), A v(1)$ & 4 & NT \\
\hline XII & - & - & - & - & + & - & + & + & - & + & At (1), Ah (1), Av (1), Aa (1) & 8 & NT \\
\hline XIII & - & - & - & - & - & - & - & + & + & + & As (2), Aa (1) & 6 & NT \\
\hline XIV & - & - & - & - & + & + & - & - & + & - & As (2), Av (1), At (1) & 8 & NT \\
\hline$X V$ & - & - & - & - & - & - & - & + & - & - & $\operatorname{Ae}(3)$ & 6 & NT \\
\hline
\end{tabular}

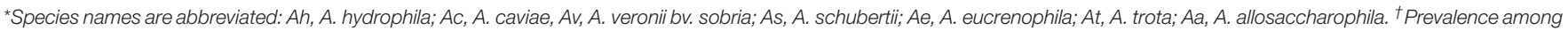

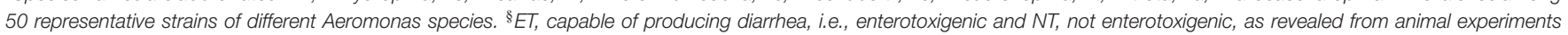
(rabbit ileal loop and suckling mice assays, Supplementary Table 2). The results of potentially virulent strains of Aeromonas spp. are shown in bold texts.

\section{DISCUSSION}

This study, to our knowledge, provides the first comprehensive investigation of spatio-temporal dynamics and toxigenic potential for Aeromonas spp. in surface water of homestead ponds in the coastal region of Bangladesh. A few earlier studies have explored the ecology of Aeromonas spp. in inland waters near Dhaka, in the central part of Bangladesh without coastal influence $(5,6,35)$. The study sites: Mathbaria and Bakergonj are located in the coastal region of Bengal delta where diarrheal diseases are prevalent. This is largely because the underground water is saline rich and thus untreated surface waters from river and ponds are used by rural people for household purposes, e.g., washing utensils and vegetables, bathing, gargling, cooking, and drinking (36). The observed occurrences of at least seven Aeromonas species including potentially toxigenic strains in homestead ponds indicate the potential threat that they could pose of gastroenteritis among the resident people in coastal villages.

The surveillance carried out during this study period shows that Aeromonas populations in these coastal tropical waters have distinct seasonal patterns. The occurrence of two peaks of Aeromonas, one during late spring (April-May) before the onset of monsoon and the other during the post-monsoon autumn (September-October), coincides with seasonality of diarrheal incidence in Bangladesh (37). Although $V$. cholerae, enterotoxigenic E. coli (ETEC), and rotavirus are commonly identified as major diarrhea causing pathogens in Bangladesh, in $\sim 45 \%$ of the cases the causative agent(s) are unidentified (38). In the routine diagnostic procedures for identifying pathogens responsible for diarrhea in Bangladesh, Aeromonas spp. is not usually targeted. The observed correlation of seasonal patterns 


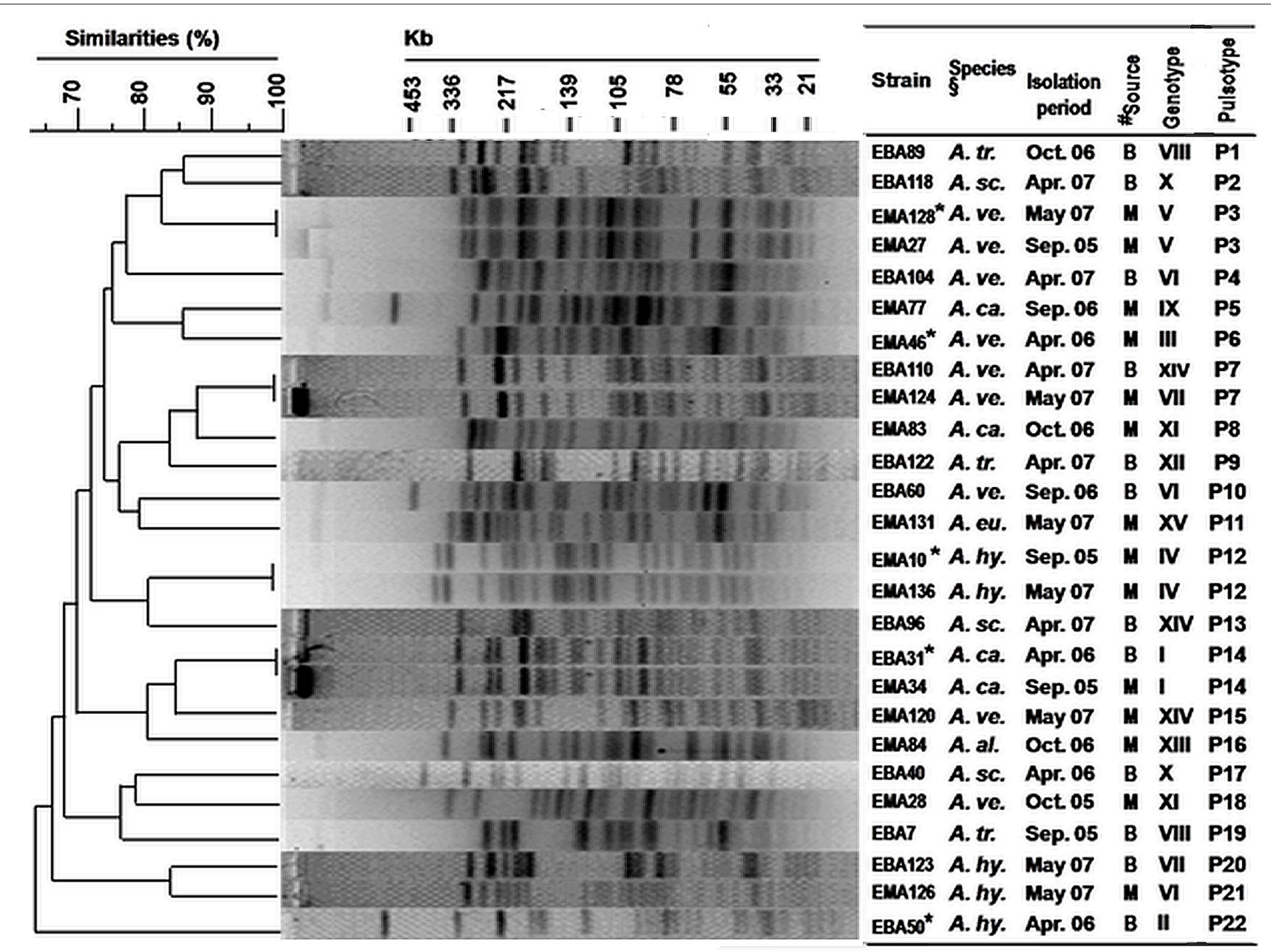

FIGURE 4 | Genetic diversity (by PFGE fingerprinting) among selected Aeromonas strains isolated from the pond waters in the coastal zone of Bangladesh. PFGE fingerprints were analyzed by using BioNumerics 4.0 software (Applied Maths Inc., TX, USA). Cluster analysis was done by the unweighted-pair group method using average (UPGMA) linkages and the band-based (Dice coefficient) option was applied. *Strains showing enterotoxigenic activities in rabbit ileal loop and suckling mice assays (Supplementary Table 2). "Species names are abbreviated. \#Isolation sources, "B" and "M" represented the coastal sites, "Bakergonj" and "Mathbaria", respectively.

of the incidence of Aeromonas populations in surface water and diarrhea cases in Bangladesh strongly suggest a role of toxigenic aeromonads as one of the causal agents of diarrheal disease in coastal villages of the Bay of Bengal.

Despite the difference in distance from the shoreline, salinity, and other marine related factors, the dynamics of the Aeromonas populations are similar, namely recurrence of population peaks in the spring and autumn, in both study areas. Previous investigations reported occurrence of only one summer peak of Aeromonas spp., in the inland surface waters of Bangladesh (35). However, a study done on the Italian coast found stochastic variation in aeromonad numbers $\left(10^{2}-10^{6}\right.$ CFU 100 $\mathrm{ml}^{-1}$ ) throughout the year, without a conspicuous seasonality (39). In Bangladesh, plankton blooms often occur in many ponds and lakes during or before the two diarrhea epidemic periods (pre- and post-monsoon). Aeromonas spp. can secrete many extracellular enzymes including chitinase, which may aid in bacterial adherence and growth on chitinous particles and plankton such as copepods, shrimps, crabs etc. (24). Degradation of the plankton and other chitin-rich substances supports rapid growth and proliferation of aeromonads and other bacteria present in the water body. In absence of such nutrients during the off-peak seasons, majority of Aeromonas populations might persist in the environment in a dormant state in which the bacterium remains viable but non-culturable (VBNC) in conventional laboratory media (40). Upon availability of nutrient under optimum bio-physicochemical conditions during the seasonal peak or when introduced into host intestine, the VBNC bacterial cells can regain culturability and become active again (41).

Temperature dependent variations in the Aeromonas populations, correlating with gastroenteritis and extra-intestinal infections caused by these organisms, in aquatic habitats have been observed previously with highest abundance in 
summer and lowest in winter $(3,8)$. The present study also observed aquatic Aeromonas populations and temperature to be correlated, with strong significance during non-monsoon period and relatively low significance during monsoon. Temperature is a vital influencing factor for many bacterial populations in coastal and oceanic habitats and at higher temperatures $\left(>20^{\circ} \mathrm{C}\right)$ bacteria rapidly utilize dissolved organic substrates $(42,43)$. Among other environmental factors, an increase in salinity up to 10 PSU favors growth of Aeromonas spp. (3). In the present study, salinity of coastal pond water was relatively low (0.0-2.4 PSU) and a significant impact of salinity on Aeromonas dynamics was not discernible. The greater isolation rate and comparatively higher number of Aeromonas spp. in the more saline Mathbaria pond water may be explained by the bacterial better adaptation to brackish water rather than freshwater.

The diversity of cultivable Aeromonas species in the study ponds was relatively higher compared to what has been reported previously for inland freshwater and sewage systems of the Bengal delta and coastal areas of Europe where only 3-4 species were reported $(5,6,39)$. The dominance of $A$. hydrophila, $A$. veronii biovar sobria, and $A$. caviae among coastal pond waters is in agreement with the earlier studies. Moreover, the present study shows $A$. schubertii is a commonly occurring species in coastal Bangladesh. Detection of Aeromonas species in this study was based on phenotypic characteristics, and this might have underestimated species diversity of cultivable coastal Aeromonas populations, including Aeromonas aquareorum, which can be misidentified as $A$. hydrophila unless amplification and sequencing of the gyrB and $r p o D$ genes are performed (44). Moreover, existence of even higher species diversity is expected because bottom sediment and aquatic organisms, including phyto- and zooplankton, which serve as important reservoirs of Aeromonas spp. were not included in this study $(35,45)$. It is evident from the present study that in addition to PFGE analysis, screening of virulence genes may aid in differentiation of strains producing identical pulsotypes (Figure 4). Further PCR analysis targeting recently known accessory virulence factors, ADP-ribosyltransferase toxin (aexT) and DNases (exu), may provide additional discriminatory results (46). The observed occurrence of identical virulence genotype in several species, or also different virulence genotypes among strains of the same species of Aeromonas appear to contradict with the hypothesis that each species possesses a distinct set of virulence genes (46). However, the whole genome sequencing (WGS) remains a future option (47), while other approaches of molecular typing, e.g., Enterobacterial Repetitive Intergenic Consensus (ERIC) PCR, and Repetitive Extragenic Palindromic (REP) PCR, in combination with sequencing of a number of housekeeping (16S rRNA, gyrB and $r p o D$ ) and virulence genes would be required to better understand the inter- and intra-species genetic diversity, clonal lineage, and horizontal gene transfer among the Aeromonas populations existing in the aquatic environment.

Results of the present study show that $A$. veronii bv. sobria, A. hydrophila, and A. caviae, which are the dominant species among the Aeromonas populations in coastal homestead ponds in Bangladesh, are potentially enterotoxigenic. This appears in agreement with the frequent occurrence of these three species reported for stool samples from patients suffering from gastroenteritis in Bangladesh (4, 5, 48). Fortunately, the coastal Aeromonas strains examined in this study were found to be susceptible to common antimicrobial agents, whereas high incidence of multi-drug resistant Aeromonas has been reported in central inland areas of Bangladesh (49).

A correlation between the pathogenic potential of Aeromonas and its $\beta$-hemolytic activity, induced by the hly $A$ and act genes has been noted in previous studies $(15,50)$. Other Aeromonas $s p p$. may produce $\alpha$-haemolytic activity by cytolysis coded by the aerA gene (32). Results of present study support the previous findings. Among the major virulence determinants associated with Aeromonas gastroenteritis occurrence of alt and act genes may synergistically induce more severe diarrhea than the alt gene alone (16). In addition, TTSS of Aeromonas (asc $V^{+}$strains) plays crucial roles in bacterial pathogenesis by translocation of ADP-ribosylating toxins directly into the host cell to induce apoptosis (21). The present study also shows that the pathogenic potential of Aeromonas strains in causing diarrhea greatly depends on a combined presence of the major virulence genes: $a s c V$, ast, and/or $h l y A$, and alt, along with cooccurrence of accessory virulence-stimulatory genes, ela, act, and aerA.

The low-altitude coastal zones of the Bengal delta is one of the most vulnerable regions to climatic disasters, including cyclones, extreme temperature and rainfall, and coastal inundations, which have profound influences on the dynamics and diversity of aquatic microorganisms, including pathogenic bacteria $(51,52)$. In the recent decade, due to increased salinity of groundwater as a consequence of sea level rise, millions of people in coastal Bangladesh has no option but to use contaminated natural surface waters for household purposes including drinking, and therefore, highly vulnerable to waterborne diseases (53). The occurrence of multiple toxigenic genes in approx. one-fifth of the representative Aeromonas strains, which could be potentially pathogenic and categorized into at least five virulence genotypes $(\mathrm{I}-\mathrm{V})$, in coastal region of Bangladesh, is of great public health implication.

\section{CONCLUSION}

The present study indicates a potential risk of pathogenic aeromonad populations in surface water of homestead ponds in the coastal region of Bangladesh. The dominant species with enterotoxigenic potential found in this study included A. veronii bv. sobria, A. hydrophila and A. caviae. Molecular characterization of virulence related genes of Aeromonas strains isolated from the Bengal delta region showed that they were highly diverse having at least 15 virulence genotypes. Cluster analysis by dendrogram using PFGE images also revealed 22 pulsotypes in 26 Aeromonas strains which were highly heterogenous genetically. A combined action of at least three of the major virulence determinants, ast-ascV-hlyA-ela-alt, and 
also indefensible synergistic mechanisms of multiple virulenceassociated genes, most likely determine the pathogenic potential of the virulent strains. A community-based epidemiological surveillance in parallel to environmental surveillance is essential to assess potentially virulent environmental genotypes of Aeromonas spp., and their correlation with diarrhea incidence in this region. The overall data presented in this study could serve as a baseline for future studies and aid intervention and preventive measures against these epidemiologically significant Aeromonas spp. thriving naturally in the aquatic environment.

\section{DATA AVAILABILITY STATEMENT}

The original contributions presented in the study are included in the article/Supplementary Material, further inquiries can be directed to the corresponding author/s.

\section{ETHICS STATEMENT}

The animal study was reviewed and approved by icddr,b Animal Experimentation Ethics Committee (AEEC). Written informed consent was obtained from the owners for the participation of their animals in this study.

\section{REFERENCES}

1. Cruz RV, Harasawa H, Lal M, Wu S, Anokhin Y, Punsalmaa B, et al. Climate change 2007: impacts, adaptation and vulnerability, chapter 10: asia (Working group iI). In: Parry ML, Canziani OF, Palutikof JP, Van der Linden PJ, Hanson CE, editors, Fourth Assessment Report of the Intergovernmental Panel on Climate Change Cambridge: Cambridge University Press (2007) p. 469-506.

2. Khan AE, Ireson A, Kovats S, Mojumder SK, Khusru A, Rahman A, et al. Drinking water salinity and maternal health in coastal Bangladesh: implications of climate change. Environ Health Perspect. (2011) 119:1328-32. doi: 10.1289/ehp.1002804

3. Kaper JB, Lockman H, Colwell RR, Joseph SW. Aeromonas hydrophila: ecology and toxigenicity of isolates from an estuary. J Appl Bacteriol. (1981) 50:359-77. doi: 10.1111/j.1365-2672.1981.tb00900.x

4. Ahmed D, Hoque A, Elahi MS, Endtz HP, Hossain MA. Bacterial aetiology of diarrhoeal diseases and antimicrobial resistance in Dhaka, Bangladesh, 20052008. Epidemiol Infect. (2012) 140:1678-84. doi: 10.1017/S0950268811002135

5. Kühn I, Albert MJ, Ansaruzzaman M, Bhuiyan NA, Alabi SA, Huys G, et al. Characterization of Aeromonas spp. isolated from humans with diarrhea, from healthy controls and from surface water in Bangladesh. J Clin Microbiol. (1997) 35:369-73. doi: 10.1128/jcm.35.2.369-373.1997

6. Rahman M, Huys G, Rahman M, Albert MJ, Kühn I, Möllby R. Persistence, transmission, and virulence characteristics of Aeromonas strains in a duckweed aquaculture-based hospital sewage water recycling plant in Bangladesh. Appl Environ Microbiol. (2007) 73:1444-51. doi: 10.1128/AEM.01901-06

7. Pianetti A, Falcioni T, Bruscolini F, Sabatini L, Sisti E, Papa S. Determination of the viability of Aeromonas hydrophila in different types of water by flow cytometry, and comparison with classical methods. Appl Environ Microbiol. (2005) 71:7948-54. doi: 10.1128/AEM.71.12.7948-7954.2005

8. Egorov AI, Best JM, Frebis CP, Karapondo MS. Occurrence of Aeromonas spp. in a random sample of drinking water distribution systems in the USA. $J$ Water Health. (2011) 9:785-98. doi: 10.2166/wh.2011.169

9. Yamada S, Matsushita S, Dejsirilert S, Kudoh Y. Incidence and clinical symptoms of Aeromonas-associated travellers' diarrhoea in Tokyo. Epidemiol Infect. (1997) 119:121-6. doi: 10.1017/S0950268897007942

\section{AUTHOR CONTRIBUTIONS}

AS and SI: resources and investigation. SN: conceptualization and formal analysis. AS and TB: investigation and writing-original draft preparation. MS: project administration and resources. F-TJ: resources. $\mathrm{NH}, \mathrm{AH}$, and $\mathrm{RC}$ : writing-review and editing. MA: supervision and writing-review and editing. All authors contributed to the article and approved the submitted version.

\section{FUNDING}

This research was funded by the National Institutes of Health research Grant 1R01A139129-01 and National Institute of Infectious Diseases (NIID). MA acknowledges with thanks the review support of Ashfaque Hossain of RAK Medical and Health Sciences University, UAE. icddr,b gratefully acknowledge the following donors who provide unrestricted support: Governments of Bangladesh, Canada, Sweden and the UK.

\section{SUPPLEMENTARY MATERIAL}

The Supplementary Material for this article can be found online at: https://www.frontiersin.org/articles/10.3389/fpubh. 2021.692166/full\#supplementary-material

10. Janda JM, Abbott SL. The genus Aeromonas: taxonomy, pathogenicity, and infection. Clin Microbiol Rev. (2010) 23:35-73. doi: 10.1128/CMR.00039-09

11. Klontz EH, Faruque AS, Das SK, Malek MA, Islam Z, Luby SP, et al. Clinical and epidemiologic features of diarrheal disease due to Aeromonas hydrophila and Plesiomonas shigelloides infections compared with those due to Vibrio cholerae non-O1 and vibrio parahaemolyticus in Bangladesh. ISRN Microbiol. (2012) 2012:654819. doi: 10.5402/2012/654819

12. Parker JL, Shaw JG. Aeromonas spp. clinical microbiology and disease. J Infect. (2011) 62:109-118. doi: 10.1016/j.jinf.2010.12.003

13. Hiransuthikul N, Tantisiriwat W, Lertutsahakul K, Vibhagool A, Boonma P. Skin and soft-tissue infections among tsunami survivors in Southern Thailand. Clin Infect Dis. (2005) 41:e93-6. doi: 10.1086/4 97372

14. Fernández-Bravo A, Figueras MJ. An update on the genus Aeromonas: taxonomy, epidemiology, and pathogenicity. Microorganisms. (2020) 8:129. doi: 10.3390/microorganisms 8010129

15. Chopra AK, Houston CW. Enterotoxins in Aeromonasassociated gastroenteritis. Microb Infect. (1999) 1:1129-137. doi: 10.1016/S1286-4579(99)00202-6

16. Sha J, Kozlova EV, Chopra AK. Role of various enterotoxins in Aeromonas hydrophila-induced gastroenteritis: generation of enterotoxin gene-deficient mutants and evaluation of their enterotoxic activity. Infect Immun. (2002) 70:1924-35. doi: 10.1128/IAI.70.4.1924-1935.2002

17. Sha J, Pillai L, Fadl AA, Galindo CL, Erova TE, Chopra AK. The type III secretion system and cytotoxic enterotoxin alter the virulence of Aeromonas hydrophila. Infect Immun. (2005) 73:6446-57. doi: 10.1128/IAI.73.10.6446-6457.2005

18. Sen M, Rodgers M. Distribution of six virulence factors in Aeromonas species isolated from us drinking water utilities: a PCR identification. J Appl Microbiol. (2004) 97:1077-86. doi: 10.1111/j.1365-2672.2004. 02398.x

19. Nam I, Joh K. Rapid detection of virulence factors of Aeromonas isolated from a trout farm by hexaplex-PCR. J. Microbiol-Seoul. (2007) 45:297-304

20. Chopra AK, Houston CW, Kurosky A. Genetic variation in related cytolytic toxins produced by different species of Aeromonas. FEMS Microbiol Lett. (1991) 78:231-7. 
21. Chacón MR, Soler L, Groisman EA, Guarro J, Figueras MJ. Type III secretion system genes in clinical Aeromonas isolates. J Clin Microbiol. (2004) 42:12857. doi: 10.1128/JCM.42.3.1285-1287.2004

22. Howard SP, Garland WJ, Green MJ, Buckley JT. Nucleotide sequence of the gene of the hole-forming toxin aerolysin of Aeromonas hydrophila. J Bacteriol. (1987) 169:2869-71. doi: 10.1128/jb.169.6.2869-2871.1987

23. Sakai DK. Loss of virulence in a protease-deficient mutant of Aeromonas salmonicida. Infect Immun. (1985) 48:146-52. doi: 10.1128/iai.48.1.146-152.1985

24. Pemberton JM, Kidd SP, Schmidt R. Secreted enzymes of Aeromonas. FEMS Microbiol Lett. (1997) 152:1-10. doi: 10.1111/j.1574-6968.1997.tb10401.x

25. Cascón A, Yugueros J, Temprano A, Sanchez M, Hernanz C, Luengo $\mathrm{JM}$, et al. A major secreted elastase is essential for pathogenicity of Aeromonas hydrophila. Infect. Immun. (2000) 68:3233-3-41. doi: 10.1128/IAI.68.6.3233-3241.2000

26. Abbott SL, Cheung WK, Janda JM. The genus Aeromonas: biochemical characteristics, atypical reactions, and phenotypic identification schemes. $J$ Clin Microbiol. (2003) 41:348-2357. doi: 10.1128/JCM.41.6.2348-2357.2003

27. Rahim Z, Khan SI, Chopra AK. Biological characterization of Aeromonas spp. isolated from the environment. Epidemiol Infect. (2004) 132:627-36. doi: 10.1017/S0950268804002298

28. CLSI. Performance Standards for Antimicrobial Susceptibility Testing (26th ed.). Wayne, PA: CLSI supplement M100CLSI S (2016). p. 62.

29. Chowdhury NR, Chakraborty S, Ramamurthy T, Nishibuchi M, Yamasaki S, Takeda Y, et al. Molecular evidence of clonal Vibrio parahaemolyticus pandemic strains. Emerg Infect Dis. (2000) 6:631-6. doi: 10.3201/eid0606.000612

30. Abdullah AI, Hart CA, Winstanley C. Molecular characterization and distribution of virulence-associated genes amongst aeromonas isolates from libya. J Appl Microbiol. (2003) 95:1001-7. doi: 10.1046/j.1365-2672.2003.02092.x

31. Kingombe CI, Huys G, Tonolla M, Albert MJ, Swings J, Peduzzi R, et al. PCR detection, characterization, and distribution of virulence genes in Aeromonas spp. Appl Environ Microbiol. (1999) 65:5293-302. doi: 10.1128/AEM.65.12.5293-5302.1999

32. Heuzenroeder MW, Wong CY, Flower RL. Distribution of two hemolytic toxin genes in clinical and environmental isolates of Aeromonas spp.: correlation with virulence in a suckling mouse model. FEMS Microbiol Lett. (1999) 174:131-6. doi: 10.1111/j.1574-6968.1999. tb13559.x

33. Sanyal SC, Singh SJ, Sen PC. Enteropathogenicity of Aeromonas hydrophila and Plesiomonas shigelloides. J Med Microbiol. (1975) 8:195-8. doi: 10.1099/00222615-8-1-195

34. Dean AG, Ching TC, Williams RG, Harden LB. Test for Escherichia coli enterotoxin in infant mice: application in a study of diarrhea in children in honolulu. J Infect Dis. (1972) 125:407-11. doi: 10.1093/infdis/12 5.4.407

35. Parveen S, Islam MS, Huq A. Abundance of Aeromonas spp. in river and lake waters in and around Dhaka, Bangladesh. J Diarrhoeal Dis. Res. (1995) 13:183-6.

36. Alam M, Sultana M, Nair GB, Sack RB, Sack DA, Siddique AK, et al. Toxigenic Vibrio cholerae in the aquatic environment of Mathbaria, Bangladesh. Appl Environ Microbiol. (2006) 72:2849-55. doi: 10.1128/AEM.72.4.2849-2855.2006

37. Alam M, Islam A, Bhuiyan NA, Rahim N, Hossain A, Khan GY, et al. Clonal transmission, dual peak, and off-season cholera in bangladesh. Infect Ecol Epidemiol. (2011) 1:7273. doi: 10.3402/iee.v1i0.7273

38. icddr,b. Responding to the 2007 floods: Record numbers of patients seek care at ICDDR,B's Dhaka Hospital. Health Sci Bull. (2007) 5.

39. Fiorentini C, Barbieri E, Falzano L, Matarrese P, Baffone W, Pianetti A, et al. Occurrence, diversity and pathogenicity of mesophilic Aeromonas in estuarine waters of the italian coast of the Adriatic Sea. J Appl Microbiol. (1998) 85:501-11. doi: 10.1046/j.1365-2672.1998.853517.x
40. Mary P, Chihib NE, Charafeddine O, Defives C, Hornez JP. Starvation survival and viable but nonculturable states in Aeromonas hydrophila. Microb Ecol. (2002) 43:250-8. doi: 10.1007/s00248-001-0046-4

41. Alam M, Sultana M, Nair GB, Siddique AK, Hasan NA, Sack RB, et al. Viable but non-culturable Vibrio cholerae o1 in biofilms in the aquatic environment and their role in cholera transmission. Proc Natl Acad Sci USA. (2007) 104:17801-06. doi: 10.1073/pnas.0705599104

42. Mahmud ZH, Neogi SB, Kassu A, Huong BTM, Jahid IK, Islam MS, et al. Occurrence, seasonality and genetic diversity of Vibrio vulnificus in coastal seaweeds and water along the Kii Channel, Japan. FEMS Microbiol Ecol. (2008) 64:209-18. doi: 10.1111/j.1574-6941.2008.00460.x

43. Neogi SB, Koch BP, Schmitt-kopplin P, Pohl C, Kattner G, Yamasaki S, et al. Biogeochemical controls on the bacterial populations in the eastern atlantic ocean. Biogeosciences. (2011) 8:3747-59. doi: 10.5194/bg-8-3747-2011

44. Aravena-Román M, Harnett GB, Riley TV, Inglis TJ, Chang BJ. Aeromonas aquariorum is widely distributed in clinical and environmental specimens and can be misidentified as Aeromonas hydrophila. J Clin Microbiol. (2011) 49:3006-8. doi: 10.1128/JCM.00472-11

45. Williams LA, Larock PA. Temporal occurrence of Vibrio species and Aeromonas hydrophila in estuarine sediments. Appl Environ. Microbiol. (1985) 50:1490-5. doi: 10.1128/aem.50.6.1490-1495.1985

46. Puthucheary SD, Puah SM, Chua KH. Molecular characterization of clinical isolates of Aeromonas species from malaysia. PLoS ONE. (2012) 7:e30205. doi: 10.1371/journal.pone.0030205

47. Salipante SJ, SenGupta DJ, Cummings LA, Land TA, Hoogestraat DR, Cookson BT. Application of whole-genome sequencing for bacterial strain typing in molecular epidemiology. J Clin Microbiol. (2015) 53:1072. doi: 10.1128/JCM.03385-14

48. Albert MJ, Ansaruzzaman M, Talukder KA, Chopra AK, Kuhn I, Rahman $\mathrm{M}$, et al. Prevalence of enterotoxin genes in Aeromonas spp. isolated from children with diarrhea, healthy controls, the environment. J Clin Microbiol. (2000) 38:3785-90. doi: 10.1128/JCM.38.10.3785-3790.2000

49. Rahman M, Huys G, Kühn I, Rahman M, Möllby R. Prevalence and transmission of antimicrobial resistance among Aeromonas populations from a duckweed aquaculture based hospital sewage water recycling system in Bangladesh. Antonie Van Leeuwenhoek. (2009) 96:313-21. doi: 10.1007/s10482-009-9348-1

50. Singh DV, Sanyal SC. Production of haemolysis and its correlation with enterotoxicity in Aeromonas spp. J Med Microbiol. (1992) 37:262-7.

51. Jutla AS, Akanda AS, Griffiths JK, Colwell RR, Islam S. Warming oceans, phytoplankton, and river discharge: implications for cholera outbreaks. Am J Trop Med Hyg. (2011) 85:303-8. doi: 10.4269/ajtmh.2011.11-0181

52. Neogi SB, Lara R, Alam M, Harder J, Yamasaki S, Colwell RR. Environmental and hydroclimatic factors influencing Vibrio populations in the estuarine zone of the bengal delta. Environ Monit Assess. (2018) 190:565. doi: 10.1007/s10661-018-6925-7

53. Wu J, Yunus M, Streatfield PK, Emch M. Association of climate variability and childhood diarrhoeal disease in rural Bangladesh 2000-2006. Epidemiol Infect. (2014) 142:1859-1868. doi: 10.1017/S095026881300277X

Conflict of Interest: $\mathrm{NH}$ and RC are employees of EzBiome Inc.

The remaining authors declare that the research was conducted in the absence of any commercial or financial relationships that could be construed as a potential conflict of interest.

Copyright (C) 2021 Sadique, Neogi, Bashar, Sultana, Johura, Islam, Hasan, Huq, Colwell and Alam. This is an open-access article distributed under the terms of the Creative Commons Attribution License (CC BY). The use, distribution or reproduction in other forums is permitted, provided the original author(s) and the copyright owner(s) are credited and that the original publication in this journal is cited, in accordance with accepted academic practice. No use, distribution or reproduction is permitted which does not comply with these terms. 